\title{
ПЕТРОФИЗИЧЕСКИЕ СВОЙСТВА ПОРОД И РАСПРЕДЕЛЕНИЕ УРАНА В ЛИЦЕВСКОМ УРАНОВОРУДНОМ РАЙОНЕ КОЛЬСКОГО ПОЛУОСТРОВА
}

\section{Каулина Т.В., Ильченко В.Л., Аведисян А.А.}

Геологический институт КНЦ РАН, Anamuты, kaulina@geoksc.apatity.ru

Лицевский урановорудный район считается одним из наиболее перспективных на Кольском полуострове $[1,5]$. Урановая минерализация связана, в основном, со средне-низкотемпературными гидротермально-метасоматическими процессами в разломных и сдвиговых зонах. Накопление урана происходило синхронно с образованием Печенгской структуры с этапами в 2.3-2.1 и 1.85-1.65 млн. лет [4-6]. Последняя по времени урановая минерализация около 400 млн лет считается наиболее перспективной $[1,5]$, ее образование, вероятно, связано с формированием щелочных интрузий Кольского региона.

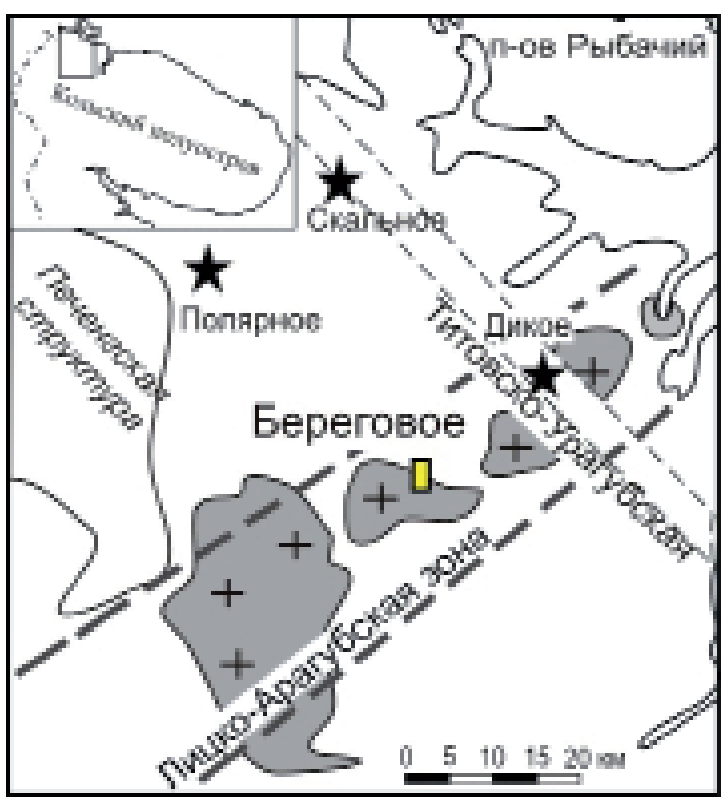

Рис. 1. Положение урановорудных участков Скальное, Дикое, Полярное и Береговое в пределах Лицевского района.

Ранее нами были изучены участки с урановой минерализацией возраста 2.3-2.2 млрд. лет (Скальное, Полярное и Дикое) [4] (рис. 1). В настоящей статье приводятся данные по химическому составу и физическим свойствам пород, вмещающих урановую минерализацию, а также по составу флюидных включений в кварце для участка Берегового с более молодой урановой минерализацией возраста 1750 и $400 \pm 50$ млн. лет.

Участок Береговое расположен в северном экзоконтакте массива Лебяжка комплекса ЛицкоАрагубских гранитоидов (рис.1) и включает несколько рудопроявлений урана: крупное - Береговое и более мелкие - Уранинитовое и Восточно-Лебяжинское [5]. Рудопроявление Береговое открыто ПО «Невскгеология〉 в 1974 г. Регионально участок расположен на пересечении субширотного разлома Чептьявр и тектонической Лицко-Арагубской зоны СВ разломов, осуществляющих структурный контроль [5].

Вмещающие породы: мигматизированные биотитовые гнейсы, гранат-биотитовые и двуслюдяные гнейсы кольской серии. Зоны гидротермально-метасоматических изменений прослеживается на поверхности участка более чем на 800 м и до 240-400 м в глубину $[5,6]$. Основные изменения хлоритизация; кроме того, отмечены: гидрослюдизация, карбонатизация и - локально - альбитизация. Урановая минерализация, выявленная в 5 скважинах, сосредоточена в линзовидных телах метасоматитов (10-20 × 2-2,5 м в длину) со средним содержанием урана $0.01 \%$. Скважинами вскрыты мелкие линзы $(1.1 \times 0.1$ м) более обогащенные ураном (до 0.14-0.2 \%)[6].

Урановая минерализация варьирует по возрасту от 1850-1750 млн. лет (уранинит и браннерит) до 400-300 млн. лет (настуран и коффинит) [5]. Первая, согласно классификации А.В. Савицкого [5] относятся к типу торий-уранового оруденения в кварц-альбит-микроклиновых и кварц-микроклиновых метасоматитах, вторая - к урановому оруденению в альбит-гидрослюдисто-хлоритовых метасоматитах. Температура образования ранних метасоматитов $500-550^{\circ} \mathrm{C}$, температура образования альбитгидрослюдисто-хлоритовых метасоматитов около $220-280^{\circ} \mathrm{C}$ ([5] и ссылки там).

Согласно исследованиям $[5,6]$ в пространственной локализации уранового оруденения исключительную роль играют структурные предпосылки. Урановая минерализации приурочена к зонам катаклаза и брекчирования, как к наиболее проницаемым зонам, которые создают благоприятные условия для рудоносных систем и рудной локализации. 


\section{Результаты петрофизических исследований}

Проведенное изучение физических свойств пород показали, что средняя плотность пород на-

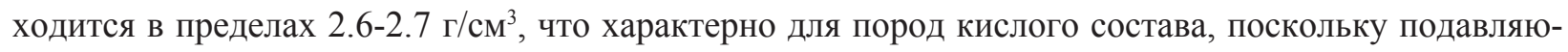
щее количество изученных образцов - гнейсы и гнейсограниты. Плотность породы - консервативный параметр, мало подверженный изменениям во времени, в отличие от показателя упругой анизотропии $\left(\mathrm{A}_{\pi}\right)$. На участке уранового рудопроявления Береговое, показатель $\mathrm{A}_{\text {п }}$ имеет максимумы (наибольшая трещиноватость пород) на участках с повышенным радиоактивным фоном, хотя развития урановой минерализации на поверхности не наблюдается (рис. 2). Повышение показателя $\mathrm{A}_{\text {п }}$ наблюдается также на рудопроявлениях Восточно-Лебяжинское (проба 21) и Уранинитовое (проба 22) (рис. 2). Распределение показателя анизотропии в образцах, отобранных ранее через урановое рудопроявление Скальное и Дикое [2] наоборот имело минимумы на участках урановых рудопроявлений, что связано, с нашей точки зрения, с залечиванием микротрещин при образовании урановой (и сопутствующей сульфидной) минерализации. Этот вывод подтверждается первыми данными рентгеновской томографии пород.

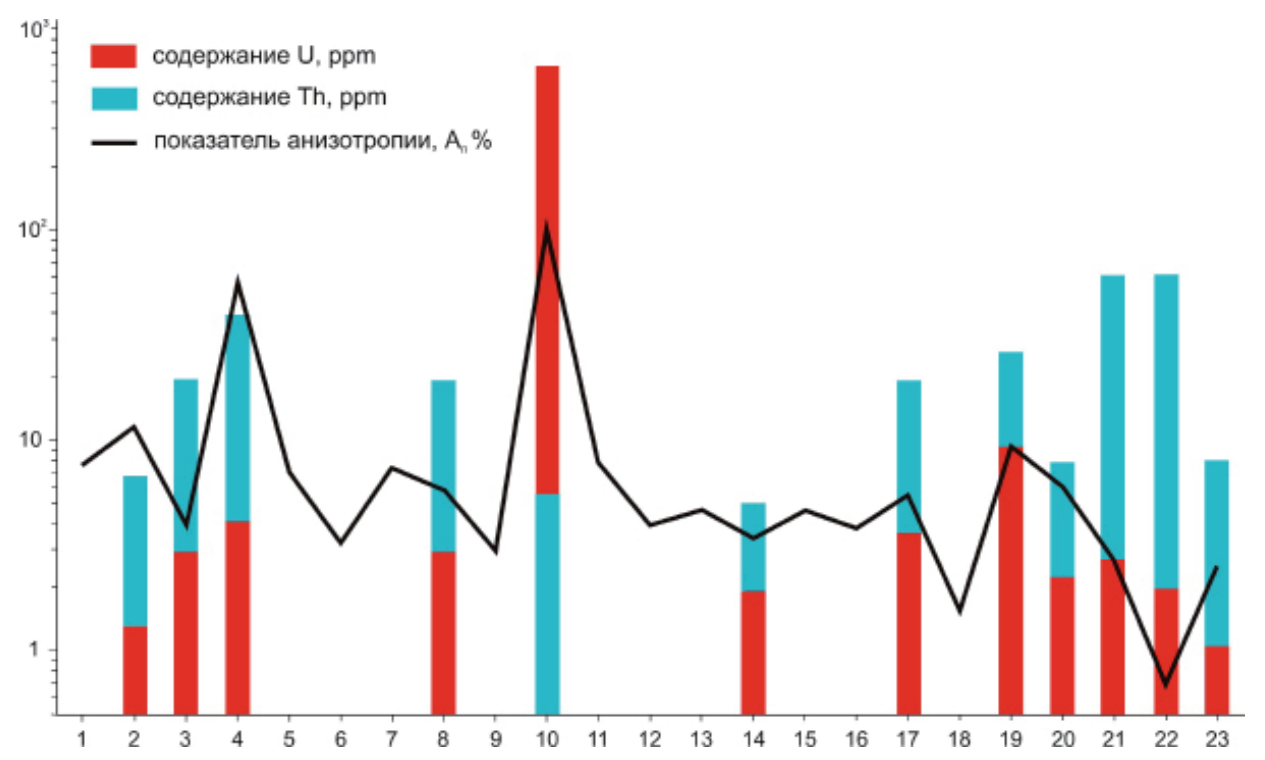

Рис. 2. Сравнение содержания урана и тория с показателем упругой анизотропии пород.

\section{Геохимические данные}

Содержание урана в гнейсах и гранитоидах относительно низкое (1-9 ppm), кроме одного образца Bt гнейса с содержанием урана 590 ppm. Содержание тория значительно выше (5-56 ppm). При этом содержание тория зависит от состава пород, а содержание урана в основном связано с физическими свойствами пород. Наблюдается корреляция содержания урана с показателем упругой анизотропии пород, то есть содержание урана повышается в наиболее проницаемых участках (рис. 2), что согласуется со структурным контролем урановых рудопроявлений Лицевского района.

\section{Состав флюидных включений в кварце}

Анализ флюидных включений в кварце на рудопроявлениях участка Береговое показал, что первичные включения во вмещающих гнейсах и гранитоидах (возраста 2.9-2.8 млрд. лет) характеризуются водно-солевой системой преимущественно $\mathrm{MgCl}_{2}-\mathrm{CaCl}_{2}$ состава с варьирующими значениями солености от 0.2 до 14.5 мас. \% NaCl-экв. Вторичные включения в кварце из крупнозернистых гранитоидов имеют $\mathrm{CaCl}_{2}$ состав водно-солевой системы при высокой солености до 20.2 мас. \% $\mathrm{NaCl}-$ экв, характерной для урановых месторождений.

Первичные включения в кварце Лицко-Арагубских гранитов (возраста 1.76 млрд. лет) характеризуются водно-солевой системой с хлоридами $\mathrm{Mg}$ и Са и соленостью от 10.5 до 18.6 мас \% $\mathrm{NaCl}$-экв. 
Содержание урана в гранитах относительно низкое (3.6 ppm). Вторичные включения в гранитах, как и включения в гигантозернистых кварцевых и кварц-полевошпатовых жилах рудопроявлений Береговое и Уранинитовое, характеризуются $\mathrm{NaCl}-\mathrm{KCl}$ составом при низко-средней солености от 1.4 до 10.5 мас \% NaCl-экв.

Таким образом, проведенные геохимические и петрофизические исследования пород участка Береговое Лицевского рудного района показали корреляцию содержаний урана с показателем упругой анизотропии пород и появлением флюида преимущественно $\mathrm{CaCl}_{2}$ состава повышенной солености. Работа выполнена в рамках темы НИР № 0231-2015-0006.

\section{Литература}

1. Афанасьева Е.Н., Михайлов В.А., Былинская Л.В., Липнер А.А., Серов Л.В. Ураноносность Кольского полуострова // Информационный сборник «Материалы по геологии месторождений урана, редких и редкоземельных металлов». М.: ВИМС, 2009. Вып. 153. С. 18-26.

2. Ильченко В.Л. О вариациях плотности и анизотропии упругих свойств архейских пород в приповерхностном залегании (на примере Центрально-Кольского мегаблока, Балтийский щит) // Геоэкология. Инженерная геология. Гидрогеология. Геокриология. 2010. №1. С. 73-79.

3. Каулина Т.В., Аведисян А.А., Томиленко А.А., Рябуха М.А., Ильченко В.Л. Флюидные включения в кварце на участках с урановой минерализацией Лицевского рудного узла Кольского полуострова // Геология и геофизика. 2017. Т. 58. № 9. С. 1334-1347.

4. Каулина Т.В., Елизаров Д.В., Лялина Л.М., Аведисян А.А., Ильченко В.Л., Самигулин Р.Р. Поведение $\mathrm{Rb}-\mathrm{Sr}$ и U-Pb систем в породах и минералах Лицевского урановорудного района (Кольский полуостров) // Матер. научной конф. «Геодинамика раннего докембрия: сходства и различия с фанерозоем» и путеводитель научных экскурсий, Петрозаводск. 2017. С. 110-113.

5. Савицкий А.В., Громов Ю.А., Мельников Е.В., Шариков П.И. Урановое оруденение Лицевского района на Кольском полуострове (Россия) // Геология рудных месторождений. 1995. №5. С. 403-416.

6. Serov L. Métallogenèse de l'uranium dans la région de Litsa (Péninsule de Kola, Russie). Docteur de l'Université Henry Poincaré (en géosciences). Soutenance publique le 24 juin 2011. Nancy. France. 166 p. 